\title{
The machine in the colony: technology, politics, and the typography of Devanagari in the early years of mechanization
}

Article

Accepted Version

Singh, V. (2018) The machine in the colony: technology, politics, and the typography of Devanagari in the early years of mechanization. Philological Encounters, 3 (4). ISSN 24519197 doi: https://doi.org/10.1163/24519197-12340051 Available at https://centaur.reading.ac.uk/75684/

It is advisable to refer to the publisher's version if you intend to cite from the work. See Guidance on citing.

To link to this article DOI: http://dx.doi.org/10.1163/24519197-12340051

Publisher: Brill

All outputs in CentAUR are protected by Intellectual Property Rights law, including copyright law. Copyright and IPR is retained by the creators or other copyright holders. Terms and conditions for use of this material are defined in the End User Agreement.

$\underline{\text { www.reading.ac.uk/centaur }}$

\section{CentAUR}


Central Archive at the University of Reading

Reading's research outputs online 


\title{
The machine in the colony: technology, politics, and the typography of Devanagari in the early years of mechanization
}

\begin{abstract}
The decades of 1930 s and 40 s in which India's struggle against British rule gained momentum also ushered in critical technological change in the way texts in many Indian languages were materially produced and represented in print. The foremost facilitators of this change were third parties precariously placed in the colonial equation. Focusing on the dilemmas and contradictions of one such concern, the New York-based Mergenthaler Linotype Company and its program for the Devanagari script, this essay examines the mechanics of the power struggle embodied in the process of technological and typographical change. Against the backdrop of India's independence movement, in deeply contested territories of language and script, the examination of typographical networks that formulated and realized this project throws new light on the richly ambivalent ideological negotiations involved - between popular and academic aspirations, altruistic and commercial enterprises, communal agendas and nationalist politics, and between imperial administration and colonial subjects.
\end{abstract}

Keywords: Devanagari, India, Linotype, Nationalism, Colonialism, Technology

On 18th June 1933 the New York Herald Tribune carried a feature story under the title "Teaching a sixth of the world to read", with only a slightly more modest subheading: now a machine is to carry literacy to India. ${ }^{1}$ This was effectively the first public announcement for not one but two products of the Brooklyn-based Mergenthaler Linotype Company (henceforth referred to as Mergenthaler). The first of these products was "Devanagari Linotype", the hot-metal Linotype machine, as adapted to compose Devanagari text. The second was "Linotype Devanagari”, a rendition - and simplification - of the Devanagari script in the form of the typeface carried on the Linotype machine. The Herald Tribune article, broadly situating this new development within the perceived educational and literary contexts of India, highlighted two questions of fundamental interest and significance to any historical enquiry - namely that the impetus for this development should have come from America, and that this seemingly altruistic foray should have come from what was primarily a commercial enterprise. To these may be added the equally critical question of why this development should have come about in 1933, not any earlier or later. It was indeed the first time that mechanical composition of the linecasting variety in any Indian script had been realized, a good three decades after the technology had been developed and established in the provinces of print in the western world. ${ }^{2}$

It can be argued that, for the most part, technologically deterministic views of typographic change have formed the basis of historical narratives of Indian scripts

\footnotetext{
1 Written by Gove Hambidge, a feature writer at the Herald Tribune, and illustrated with photographs from William Norman Brown. "How Devanagari looks in machine-set characters": a sample of Linotype Devanagari, making its first public appearance anywhere in print, was reproduced on page 21.

2 Linecasting refers to mechanical composition systems (such as Linotype, Intertype) where a line of matrices is assembled to cast a full line, as opposed to individual pieces of type. A few earlier instances of Devanagari mechanical composition did exist prior to the 1930s: in the form of smaller-scale machines like typewriters as well as the Monotype Corporation's hot-metal Devanagari project initiated in 1921. The Mergenthaler Linotype Company followed its Devanagari machine of 1933 with a Gujarati adaptation in 1935 and Bengali in 1936.
} 
and their material representation. 3 Persisting with the common but reductive explanation that all typographic limitations have been limitations of technology, however, sidesteps a significant range of questions - not only those about the place and role of typographic networks within larger social and political realms, but also of power relations within the processes of design and technology involved in enabling text-based communication. Unsurprisingly, histories recounted from the point of view of the makers and manufacturers often revolve around origin and dissemination: narratives of invention and innovation in a specific time and place and its subsequent transmission elsewhere, positing the latter process as well as geographies largely inconsequential.4

Technology and its manifestations - the printing press, perhaps most famously have been cast as the agents, or the historical actors, in the process of change. ${ }^{5}$ But it is useful to acknowledge that technology also comes in the purview of other kinds of agency, particularly that of its adopters and eventual users in a given social circumstance. It is in turn "acted upon" by forces and entities that have usually not been accorded significant positions in narratives that insist on portraying technological progress as the most significant force, or as an autonomous phenomenon existing outside of social, cultural, and political settings. A machine could indeed be the agent of change but time and location matter beyond its point of origin, and as this essay will argue, beyond notions of departure and arrival that are lodged firmly in expressions like "the coming of print" and "technology transfer". In the case of Linotype in India, the argument can be extended precisely by subverting the long-standing association of the machine with movement and examining, as it were, the machine at rest: not only grounded in specific cultural circumstance but also sans the universality of its assumed function. The same machine that represented an innovation in twentieth-century New York, an object of interest and an exhibit in imperial London, could serve as an instrument of power, or a site for social struggle, in colonial Bombay and Calcutta. This essay will concern itself with some of the less examined aspects of the acculturation of the Linotype in the context of its adaptation to compose Devanagari.

\section{The machine in the making: conflict, collusion, and the mechanics of empire}

The Indian subcontinent is home to a rich diversity of languages and scripts - well over 1500 languages are spoken within its wide expanse, with more than twenty of these possessing upwards of a million speakers each. There have been twenty-two officially recognised languages in the country, written mainly in ten scripts (i.e. many languages often share the same script). ${ }^{6}$ These scripts can be broadly divided into two geographical groups: northern and southern. The northern Indian scripts are

\footnotetext{
3 This is predominantly the case where type and typography are in focus, see for instance Bapurao $\mathrm{S}$. Naik, Typography of Devanagari (Bombay: Directorate of Languages, 1971); B. S. Kesavan, History of Printing and Publishing in India: a Story of Cultural Reawakening (New Delhi: National Book Trust, 1997). See also, Richard Southall, Printer's Type in the Twentieth Century: Manufacturing and Design Methods (New Castle and London: The British Library and Oak Knoll Press, 2005). On the other hand in book history related enquiries technology often features as an incidental or unproblematic detail, or as a parallel and autonomous historical strand. See Francesca Orsini (ed.) The History of the Book in South Asia (Surrey: Ashgate, 2013).
}

${ }^{4}$ See for instance, Andrew Boag and Christopher Burke (eds.) History of the Monotype Corporation (London: PHS and Vanbrugh Press, 2014); Frank Romano, History of the Linotype Company (Rochester: RIT Press, 2014).

5 Elizabeth L. Eisenstein, The Printing Press as an Agent of Change: Communications and Cultural Transformations in Early-Modern Europe (Cambridge: Cambridge University Press, 1979).

${ }^{6}$ Based on the Census of India (2001), which lists 22 scheduled languages and 100 non-scheduled languages: a "scheduled" language refers to the Eighth Schedule of the Indian Constitution which lists officially recognized languages in the country. 
Devanagari, Gurmukhi, Gujarati, Bengali/Assamese, and Oriya. Southern Indian scripts comprise Tamil, Telugu, Kannada and Malayalam. Perso-Arabic has been used extensively in many parts in India and across the subcontinent, in Pakistan and Bangladesh. What is of greater significance in this context, however, is that regions are not exclusive in their use of language and script - it is certainly not unusual to find more than two in use at the same time.

This diversity has had a long and varied history - on some occasions having been celebrated as a desirable and enviable quality, and on others, disapproved of as a source of confusion and unnecessary complication, especially in the context of having to print in more than one language and script within a "national" or "regional" framework. The relationship of language and script to printing in the subcontinent constitutes a complex history, having been driven by the interests and the involvement of diverse bodies: missionaries, merchants, colonisers, local elites, administrators, and colonial subjects. Their respective, often intertwining, approaches to textual traditions, scholarship, access to information and its circulation have historically prompted a variety of responses and transformations. Various languages like Tamil, Bengali, Persian, and Urdu/Hindi gained prominence in print in different regions, at different junctures, alongside projects of codification and formalisation that extended debates over language and script, particularly in relation to the definition culture, tradition, and identity.7 The most interesting manifestations of this phenomenon are to be found in eighteenth- and nineteenthcentury printing in Indian scripts, especially as a British enterprise. ${ }^{8}$ The debate over language and script has been a long and continuing one, leading Orientalist and linguistic scholars in the nineteenth century to ponder not only a hierarchy of the most prominent or "appropriate" scripts for a language and a region, but also to make a case for the substitution of one script with another - or at times simply to abolish the use of the numerous scripts of India and replace them with the Latin alphabet.9 Sporadic instances of this debate continued to appear throughout the colonial period, and with the gradual strengthening of nationalist sensibilities from the latter half of the nineteenth century, the issue regained prominence by transforming the hierarchical colonial frameworks into an indigenized quest for a "national" language and script.10 The nature of this debate tended to remain limited to political assertions or nationalistic arguments, without necessarily leading to a greater interest in the scholarly and practical aspects of the scripts and their historical development. Unsurprisingly, across this period the most prominent typographic development in the subcontinent were initiated and carried out by missionaries of various denominations, or colonial administrators and institutions, using Indian labour and local workforce that they subsequently trained. ${ }^{11}$

7 For a detailed overview see Vasudha Dalmia, The Nationalization of Hindu Traditions: Bharatendu Harischandra and Nineteenth-Century Banaras (Delhi: Oxford University Press, 1997); Christopher R. King, One Language, Two Scripts: the Hindi Movement in Nineteenth Century North India (Bombay: Oxford University Press, 1994). For the early history of printing in various Indian languages see Anant K. Priolkar, The Printing Press in India: its Beginnings and Early Development (Bombay: Marathi Samshodhana Mandala, 1958).

${ }^{8}$ For instance the projects of linguistic discrimination initiated in the works of British scholars at the College of Fort William in Calcutta at the turn of the nineteenth century. Sisir Kumar Das, Sahibs and Munshis: an Account of the College of Fort William (New Delhi: Orion Publications, 1978), 36-59.

${ }^{9}$ See for instance, Charles Trevelyan, The Application of the Roman Alphabet to All the Oriental Languages (Serampore: Serampore Press, 1834); Monier Williams (ed.), Original Papers Illustrating the History of the Application of the Roman Alphabet to the Languages of India (London: Longmans, Brown, Green, Longmans, and Roberts, 1859).

10 Vasudha Dalmia, The Nationalization of Hindu Traditions, 146-180.

11 For example the Serampore Mission Press cut and cast the first types for several scripts in the country, or the American Mission Press in Bombay, where new systems of Devanagari type composition were introduced. Individuals in the service of the East India Company, like N. B. Halhed and Charles Wilkins introduced types for Bengali and Nastaliq. Bapurao S. Naik, Typography of Devanagari, 268-300; See also Fiona G. E. Ross, The Printed Bengali Character and its Evolution (Surrey: Curzon Press, 1999). 
However, for the project of mechanical typesetting in the context of colonial India, there are strong reasons for a reversal of the customary formulation of technological enterprise - the idea that initiative from the metropoles drove improvements in an otherwise stagnant or retrogressive colony. It is known that in the early decades of the twentieth century, mechanical composition for Indian scripts was under consideration by manufacturers of typesetting machinery - invariably situated outside India, but with representatives in the country. ${ }^{12}$ What has not been examined, however, is the motivation behind these considerations, and the ample evidence that such developments had long been in demand by Indian printers and publishers by the time the demand was acknowledged by manufacturing companies in the 1920 s and 30s.13 Social and economical imperatives for faster composition and larger circulation of printed matter across the country had come to the fore with the rise of nationalism, the independence movement, and the politics of language and script that emerged alongside. With limited recourse to technical know-how, particularly in an age of proprietary technologies, colonial printing establishments had responded with various schemes to make hand composition in Indian scripts faster and easier to the extent that it was possible, and by approaching manufacturers who could undertake the requisite technical experimentation for mechanical composition. ${ }^{14}$

It was hardly incidental that in the multilingual landscape of the subcontinent the mechanization of Indian scripts began with a distinct focus on one script: Devanagari. In a linguistically diverse region, the rise of Hindi as the putative "national" language, and Devanagari as the related script, was a phenomenon deeply entrenched in political and communal battles that had been waged since the midnineteenth century. A manifest outcome of this ongoing strife was the establishment in 1893 of the "Nagari Pracharini Sabha", one of several partisan bodies emanating from the religious centre of Banaras (Varanasi) promoting and advocating the use of Hindi and Devanagari. Intensifying the linguistic and communal divisions already present, in 1900 the status of both language and script had been ensconced in the "MacDonnell moment" when under the colonial regime Hindi, written in Devanagari characters, was recognized as an official language distinct from Urdu, written in Perso-Arabic characters. ${ }^{15}$

It was also not a coincidence that projects at the two major companies in the field of mechanical typesetting, Linotype and Monotype, were in fact initiated by colonial subjects - individuals, supported by local funds as well as local agendas, who made their way to London and New York to represent and pursue the demand in the colony. Debates on language and script, often along divisive lines, had been instigated by prominent figures of the period in the spheres of literature, publishing, politics, and religion in India. However, in the earliest stages of what became the Devanagari Linotype project, leading to the development of a machine for mechanically typesetting the script, four very different personalities were involved -

\footnotetext{
12 Graham Shaw, "Printing in Devanagari: the Evolution of Types in Devanagari Script", Monotype Recorder, new series no.2 (1980): 28-32. See also Ross, The Printed Bengali Character, 134-179.

13 Modern machines had entered the South Asian market in the early 1900 and by 1914 products derived not only from European technical expertise but also from American enterprise. David Arnold, Machines and the Making of Modern India (Chicago and London: University of Chicago Press, 2013) 40-42. Besides inquiries from Indian printing establishments to prominent manufacturers like Linotype and Monotype, the demand for mechanical typesetting also fuelled experiments like the Bhisotype, and adaptations of the typewriter and the Varityper to compose various Indian scripts.
} 14 The Kirloskar Press in Pune, for instance, introduced a simplified system of typesetting Devanagari for
its eponymous magazine in the 1920s. See Naik, Typography of Devanagari, vol.2, 329-333.

15 Alok Rai, Hindi Nationalism (New Delhi: Orient Longman, 2001), 17-49. See also Akshaya Mukul, Gita Press and the Making of Hindu India (Noida: HarperCollins, 2015), 4-8. 
Hari G. Govil, the "inventor" of Devanagari Linotype; 16 Chauncey H. Griffith, assistant to the president and later vice president with responsibility for typographic development at Mergenthaler; Harold H. Bender, Professor of Indo-Germanic Philology at Princeton University and chief consultant to Mergenthaler on foreign scripts; and William Norman Brown, the first Professor of Sanskrit at the University of Pennsylvania, and consultant to Mergenthaler on its various Indian and South Asian projects from the 1930 s to 1959.

Hari Govil, the flag-bearer for Devanagari in New York, had been educated at the Banaras Hindu University, an institution then newly founded by the prominent political and Hindu nationalist figure Madan Mohan Malaviya, who was also the founder of the Hindu Mahasabha.17 Govil himself founded the India Society of America and the India Center in New York in the 1920s, promoting "a more accurate knowledge of the Hindu people, their life and ideals" ${ }^{18} \mathrm{He}$ had made his way to New York, and Mergenthaler Linotype, via London where his proposal for a Devanagari machine appears not to have been entertained - a portent of the apathy from the London offices of Linotype that would persist even after the project's eventual completion in New York.

Mechanical composition had already made inroads in other regions of the world, and in other scripts besides the Latin alphabet, by the time serious consideration to the Indian market was given by the companies developing the machines. It was, again, not incidental that starting in the early decades of the twentieth century, across an extended period of proprietary technology and corporate hegemony in type-making, the companies involved in the mechanization of Indian scripts functioned within the ideological framework of empire - rarely accommodating colonial subjects as historical actors, but instead as temporarily useful informants, echoing the "sahibs and munshis" mode of engagement of a different era. ${ }^{19}$ To the extent that typographic projects for Indian scripts featured in their own accounts and publicity literature, official company narratives often co-opted the initiative for these developments - not unlike the Herald Tribune headline - presenting them as their own altruistic ventures for the benefit of the colony. In the development of a "Devanagari machine", though, both nationalist and orientalist points of view would appear to have found common cause. ${ }^{20}$ The typographic network that enabled mechanical typesetting of Devanagari contributed to the maintenance of established hierarchies - both within India along communal lines, and internationally in a colonial framework.

16 Hari G. Govil, US Patent for "Typographical Font”, (filed 1933, granted 1937). As a matter of fact, what Govil patented was not the machine but the "scheme" for the adaptation of Devanagari by the method of splitting and combining characters.

17 Several Hindu nationalist institutions were indeed founded in the 1920s, including the Rashtriya Swayamsevak Sangh, to pursue communal agendas. See also, Sandria B. Freitag, Collective Action and Community: Public Arenas and the Emergence of Communalism in North India (Delhi: Oxford University Press, 1990).

18 "India's Culture", The Brooklyn Daily Eagle (13 April 1930). Govil's background and activities in New York are described briefly in Sarah A. Fedirka, Towards a Locational Modernism: Little Magazines and the Modernist Geographical Imagination (Arizona State University, 2008), 185.

19 Sisir Kumar Das, Sahibs and Munshis: An Account of the College of Fort William (New Delhi: Orion Publications, 1978).

20 A schismatic definition of a pure and original "Hindu culture", with Sanskrit as the language of its classical antiquity, had been propounded by British and European scholars and Indologists and taken up enthusiastically by the nationalists. See for instance, Christopher R. King, One Language, Two Scripts: the Hindi Movement in Nineteenth Century North India (Bombay: Oxford University Press, 1994), 2333. Both Bender and Brown were classical scholars for whom the predominance of Sanskrit, and by implication Devanagari, was not a questionable concern. The emphasis on defining the project as that for a "Devanagari machine" came from Bender. 


\section{The machine in transit: New York, London, Calcutta, Bombay, and the launch of Devanagari Linotype in India}

Little is known about Hari Govil's activities before the 1920s, the time of his arrival in America - only a biographical newspaper report from 1930 gives an embellished account of his life up to that point. ${ }^{21}$ On $5^{\text {th }}$ April 1932, Govil was officially retained under contract from Mergenthaler to provide his services in adapting Devanagari to the Linotype according to his proposed scheme.22 (Figure 1) The necessary push, and backing, for this development may have been provided by the large-scale typesetting requirements for a project initiated at Princeton University. The Princeton Alumni Weekly of 5th April, 1929 carried a report on a project to catalogue, edit, and publish the manuscripts in the Garrett Collection. 23 The report went on to specify that the Princeton University Press, who were to handle the publishing, would employ the machines and typefaces produced by Mergenthaler, equipped with various scripts. The plausibility of this project serving as the additional impetus is strengthened by the fact that Harold Bender, the chief consultant to Mergenthaler on the Devanagari project, was himself part of the editorial committee for the publication of the Garrett manuscripts. 24 On the other hand, the Monotype Corporation in London had initiated its own Devanagari program - as early as 1921 but not successfully implemented till 1930. ${ }^{25}$ Linotype's interest may also have been occasioned as a competitive response to this development. It is also likely that in the general economic slump of the period Mergenthaler saw investments in a new market less as a risky proposition and more as a diversification of its interests. Added to that was a certain assurance of academic utility for the machines - highlighted by the potentiality of a healthy clientele in the universities of America and abroad. ${ }^{26}$

The entire process of design and manufacture took place in New York. The process of development as planned and executed by Mergenthaler was remarkably smooth. Studies and reports had been made, drawings prepared by Mergenthaler's staff under Govil's supervision, proofs checked and corrections incorporated to the extent of general approval from all involved. In addition, publicity matter had been given due consideration and the Devanagari Linotype machine was officially ready for launch in April 1933 - almost exactly a year from Govil's official engagement in the project. It is from this point on that the process became more involved, encountering first the issues of positioning this development within the dynamics of international relations, and subsequently landing in the complications of reception and response that it had till then contrived to disregard.

21 See “India’s Culture”, The Brooklyn Daily Eagle (13 April 1930).

22 Letter from C. H. Griffith to T. J. Mercer, Vice-President in charge of audits (5 April 1932). Box-P3627, File 919-1, NMAH

23 "Project to Further Human Knowledge: Garrett Collection of Manuscripts to be Edited - University Press to Publish Results with New Equipment”, The Princeton Alumni Weekly (5 April 1929) 787.

24 The Garrett Collection mainly comprised of Arabic, Persian, Ottoman Turkish, and other Islamic manuscripts and also included Egyptian papyri and Meso-American material. The collection, formally donated only in 1942, derived from Princeton alumnus (and Olympic champion) Robert Garrett, an eminent collector of medieval manuscripts who also underwrote the University's purchases in the $1920 \mathrm{~s}$ towards enlarging its collections.

25 Monotype Archives, Salfords. “Index card for Series 155 Devanagari” (31 December 1921). The origins and details of Monotype's Devanagari development are not within the scope of this essay and have been covered elsewhere in Vaibhav Singh, "Devanagari type in the twentieth century: motivations, imperatives, technology, and the design process" (Unpublished PhD thesis, 2017).

${ }^{26}$ Letter from C. H. Griffith to H. H. Bender (14 March 1933). Box-P3627, File 919-1, NMAH. Bender had indicated that the Harvard University Press would be a potential purchaser: it had "published a large number of Sanskrit texts in Devanagari", under the Harvard Oriental Series. 
Govil's contract with Mergenthaler required not only that he should demonstrate the machine as and when required, but also that he should sell two Linotype machines to customers in India, at prices and on terms acceptable to Mergenthaler. ${ }^{27}$ Within this arrangement Govil was to leave for Calcutta, where it was hoped the local offices of Linotype would provide him "a native mechanic skilled in the care and operation of the machine". ${ }^{28}$ Mergenthaler also suggested that Govil should stop at London on his way to India, installing a machine at Linotype \& Machinery (henceforth referred to as L\&M), the London branch that managed the Company's Indian operation, so that its workings could be demonstrated to possible Indian visitors. Remarkably though, regarding publicity for the new development, Govil was advised not to associate the machine with the British company directly. It is significant that the question of bilateral relations and contemporary political circumstances had been a secondary one throughout the period of the Devanagari development in America, and the question of acceptability revolved largely around technical and aesthetic dimensions. ${ }^{29}$ Against the backdrop of the rising nationalistic movement in India, it soon became clear that the British company was in no position to adopt more than a tentative approach to commercially pushing the new project, especially faced with factors outside the province of technological innovation and practical utility. Professional relationships and work practices in this scenario were also serious obstacles, as early communication between London and Calcutta immediately revealed. A. J. May, the manager of Linotype's Calcutta office, on being informed of having to work with Govil, who had not yet sailed for India, wrote:

It will be a rather difficult position, as I have had a little experience before of Indians who have a certain amount of foreign education grafted on. It will also be a difficult position for anyone of our staff if they have to go out and erect the machine [...] If I send our best Indian mechanic, I can visualise the time he will have, and if a European goes, he cannot be expected to work under instructions of an Indian in this country. Even our customers would consider this 'losing of face'.30

Govil reached Calcutta on 11th August, the first Devanagari Linotype arrived there on $13^{\text {th }}$ September and was erected on 15 September 1933 - observing social protocol and acceptable arrangements. In the period before the arrival of the machine, Govil began training two operators with the aid of dummy keyboards. The machine was exhibited and a demonstration made to representatives from leading newspapers in Calcutta and a few others from the publishing industry. The second machine arrived in Bombay on 8 November 1933, and a demonstration was held at the showroom of L\&M’s Bombay office on 14 December. Govil travelled extensively in India - not necessarily in accordance with plans envisaged by Mergenthaler Linotype and L\&M - ostensibly in connection with the publicity of the Devanagari machine but also lecturing and addressing meetings on the adoption of Devanagari as "an all-India script". ${ }^{11}$ This was a trajectory of Govil's own making and went against the general

27 Letter from C. H. Griffith to Norman Dodge, President (10 May 1933). Box-P3627, File 919-1, NMAH

28 Ibid. It is not clear why the Company made this assumption, but it is likely that it overestimated labour availability for a new machine. The situation was compounded by the fact that Linotype's Calcutta office was to make the necessary arrangements through instructions from the British company.

29 This does not imply that international politics was completely disregarded in the developmentBender's inquiry into Govil's qualifications had cleared him as not being from the group of "men of the publicity, and especially propaganda types, representing some particular phases of Indian political or religious sectarian opinion". H. H. Bender, "Devanagari on the Linotype", 20-21 (25 January 1932). BoxP3627, File 919-1, NMAH

30 Letter from A. J. May to V. E. Walker (24 May 1933). Box-P3627, File 919-1, NMAH

31 Hari Govil, "Report on Govil's visit to India for introducing the Devanagari Linotype" (3 April 1934). Govil gave talks at All India Hindu Conference and Industrial Exhibition, Ajmer; Society for the promotion of Hindi Literature, Indore; and the Indian Oriental Conference, Baroda. 
approach of Mergenthaler, who did not stand to gain anything from offering partisan support to any one script over another. However, renewed negotiations of language and script priorities were instantly set in motion by the introduction of the Devanagari Linotype.

By February 1934, one Devanagari Linotype had been sold - to the Prabasi Press, Calcutta run by Kedarnath Chatterjee, who having acquired the machine set about completely revising the keyboard layout, composition scheme, and the design of the typeface that it carried. This revision, which soon officially replaced Mergenthaler's original offering entirely, achieved results that were not vastly different from the original, and in many instances even inferior to it, but it was found "acceptable". 32

Govil managed to secure the sale of the second machine, fulfilling his contractual obligation, to Krishna Prasad Dar of the Allahabad Law Journal Press before returning to America.33 Once he had departed, it appears that the Calcutta office again found itself at the centre of criticism and activity that it was not equipped to handle, but also not in a position to disregard. In his report submitted to Mergenthaler, Govil bemoaned the lack of trained operators for Linotype composition in Calcutta and reported that the Indian offices of L\&M were reluctant to spend money to secure them. Additionally, he noted:

I found that the present staff of the Linotype Company is in no position to help the sales of the Devanagari Linotype. There is no one on the staff who knows Devanagari or understands anything about it. I am uneasy as to the fate of future sales during my absence. There is nothing I know that is being done by the India office to promote or stimulate sales of Devanagari Linotype while I am away. I must however say that Mr May assisted me in every possible way. 34

This seems to have compounded a series of conflicting impressions and predictions as to the immediate and future prospects of the development. From London, V. E. Walker, the deputy chairman and managing director of L\&M, echoed A. J. May's assessment that "it is generally thought that the prospect of the sale of a substantial number of machines is rather remote". ${ }^{35}$ Bender retaliated by pointing out Walker's continuing scepticism toward the project, and questioned Walker's understanding of the situation:

After all, Mr Walker bases his comments on reports from Calcutta, a region where Devanagari is not prevalent. The Devanagari machine should be pushed in regions where Devanagari is used..$^{6}$

It is useful to reiterate here that Mergenthaler had developed the machine specifically for Devanagari with an understanding that it was the most widely used script in the country, and then dispatched the machine to their Calcutta office that functioned as their centre of operations in India. However, given that the office was

\footnotetext{
32 This acceptability meant rather less than what Mergenthaler would have wished for. Purchasing the machine gave Chatterjee a license in matters relating to its improvement, and since his Press was the machine's main users at this stage, he had a greater say in determining acceptability - particularly for his own use - than others who provided criticisms or suggested revisions.

33 Both machines were sold at a substantially discounted price and on a hire purchase contract, spread over three years for one, and fifty-seven months for the other. Letter from V. E. Walker to C. H. Griffith (14 March 1934). Box-P3627, File 919-1, NMAH

34 “Report on Govil's visit to India for introducing the Devanagari Linotype" (3 April 1934) 10-11.

35 Letter from V. E. Walker to C. H. Griffith (14 March 1934). Box-P3627, File 919-1, NMAH

36 Letter from H. H. Bender to C. H. Griffith (19 May 1934) 2. Box-P3627, File 919-1, NMAH. Bender wrote: "I have the impression that Mr Walker cherishes a certain prejudice against the Govil scheme; that he really doesn't believe in it; but that he will, of course, do all that your Company desires him to do in furthering it in India."
} 
located squarely in a region where the predominant language and script were Bengali, the employees of the Company as well as the prospective users of Mergenthaler's new offering could thus look askance at its immediate relevance and the apparent linguistic dissonance. The gradual shift in considerations from the limitations of the machine to the geography and affiliation of its users was only the beginning of a struggle that would soon turn into an elaborate project involving multiple individual and institutional actors - a project to sidestep questions of local technical capability and regain control of the script itself by "reforming" it.

In the immediate aftermath of Govil's visit, as the Calcutta office went about seeking possibilities for the Devanagari machine's sale in India it ended up relaying statements of opinion and opposition from its primary and potential client base: newspaper proprietors, text-book publishers, and various government printing offices. ${ }^{37}$ These were unfavourable criticisms - in most cases justifiably so - of the peculiarities of the Linotype Devanagari design. Coming from local individuals, presses, and other printing establishments these responses were generally without critical or constructive commentary. The Calcutta office, unable to address the concerns directly, awaited solutions from London, and London merely transmitted their reports verbatim to New York, which led Griffith to declaim:

On the whole, the reports from Calcutta [...] clearly indicate complete lack of sympathy with or perhaps a complete misunderstanding of this entire development. I am inclined to feel that the latter is the case, and if we cannot obtain a closer and more sympathetic cooperation I do not think it would be good policy for us to carry on further. 38

For Mergenthaler, the lack of constructive detail in the criticisms coming from India made it difficult to determine "accurately what is required" - information was either withheld by parties bargaining in their own interests or not forthcoming from establishments seeking a more prominent role in the process than Mergenthaler was willing to concede. 39 The determination of specify and "usable information" was also compounded by the political climate where the likelihood of the machine's unacceptability due to it being a "British product" featured prominently in the launch and throughout the publicity campaign. With national sentiment in India "not very cordial to British business", Govil reported that he had made it a point to "emphasize the fact that the Devanagari Linotype was an American product" - and that he believed the reason why the Indian press welcomed the machine with any enthusiasm and gave it wide coverage was "precisely because it was not British, but American" and developed in collaboration with one of their own countrymen..$^{\circ} \mathrm{In}$ response to the criticisms and reports of diminishing sales possibilities, Harold Bender went so far as to suggest an outright two-pronged approach - he recommended reminding those customers who were part of the British administration, like the various offices and colonial institutions in India, that "the company producing the machine is British"; and for those customers who were "primarily Indian and anti-British", like various vernacular newspapers, the fact that the machine had been invented and developed in America was to be promoted.41

37 Among those who were consulted and offered criticisms were proprietors of leading newspapers like Hindustan Times, National Call, The Leader; and printing establishments like The Job Press, Cawnpore; Radhey Shyam Press, Bareilly; The Indian Press, Allahabad; The Law Journal Press, Allahabad; and the Kadga Vilas Press, Patna.

38 Letter from C. H. Griffith to Norman Dodge (11 June 1934). Box-P3627, File 919-1, NMAH

39 Report by Tom King (20 April 1934): "[Mr Ghosh of the Indian Press] does not like our face, which he considers much too light." Report by Tom King (11 May 1934): "our face is not acceptable and must be recut to resemble the types of the Gujerati Type Foundry, Bombay, if it is to become popular.”

40 Letter from H. G. Govil to C. H. Griffith (18 June 1934). Box-P3627, File 919-1, NMAH

${ }^{41}$ Letter from H. H. Bender to C. H. Griffith (19 May 1934) 9. Box-P3627, File 919-1, NMAH 
However, the bone of contention was not merely the political affiliations of the machine's development, but also the autonomous way in which it had been developed. In the wake of Govil's visit and publicising activities, some prominent newspaper publishers

... thought that L\&M Ltd [London] and not MLC [i.e. Mergenthaler, New York], had been responsible for Mr Govil's visit and they could not understand [...] why such an experiment was made in this country without previously referring the all-important matter of the type face to printing experts in the territory into which it was proposed to introduce the machine. $4^{2}$

It is interesting to recall in this context Bender's rationale, outlined in his report, for going through with the development first and seeking approval from the machine's potential users at a later stage. 43 The primary concern had been to demonstrate the new system as a practicable alternative, offering ease and speed of composition that was, at least in theory, far greater than what could be achieved by hand-setting Devanagari type. 44 The development had been carried out in the belief that its "obvious" advantages would incentivise progressive establishments to make the investment required. Contrary to these expectations, Mergenthaler would soon find out, printing establishments in India were more willing to accept a slower method or a limitation-ridden development that acknowledged local agency rather than one that appeared to have been transported and imposed.

\section{The machine at rest: Devanagari Linotype and the script reform movement}

Towards the end of October 1934, the Indian National Congress - the largest and most influential political body in India's independence movement - was scheduled to hold a meeting in Bombay. Finding this an excellent opportunity for a trial run, the local offices of L\&M sought permission from the meeting's arrangements committee to exhibit the Devanagari Linotype machine at the venue, and also probe the possibility of a book by Mahatma Gandhi to be composed mechanically. 45 Linotype's Calcutta office had been given to understand by the prospective publisher that Gandhi had "specified that the book shall be set by linotype [sic]". ${ }^{46}$ Even earlier, William Norman Brown - in his capacity as a "disinterested scholar" and a consultant to Mergenthaler - had asked Richard Gregg, a close friend of Gandhi's, to broach the subject of Linotype's Devanagari development, with which Gregg himself had been much impressed.47 Given the sceptical reception of the Devanagari Linotype over the first year of its existence, any favourable consideration by a national body held great significance for the machine's prospects in India.

42 Report by Tom King (11 May 1934). Box-P3627, File 919-1, NMAH.

${ }^{43}$ H. H. Bender, “Devanagari on the Linotype”, (25 January 1932). Box-P3627, File 919-1, NMAH

44 This assumption did not take into account other factors involved in text composition besides technology, such as labour. The following section provides a relevant example.

45 W. N. Brown, "Report no.1" (September 1934). Box-P3627, File 919-2, NMAH. Letter from V. E. Walker to Norman Dodge (11 September 1934). Box-P3627, File 919-2, NMAH

46 As it turned out, it had been a "complete misunderstanding", but irrespective of the veracity of the statement, the prospect was too important for Mergenthaler to ignore in view of Gandhi's national standing and potential influence in getting the machine accepted nationwide. This misunderstanding also lent urgency to the development of Mergenthaler's revised Devanagari typeface which, within a year, replaced the original.

47 Brown did not think it wise to go and see Gandhi himself, as he considered there was "too much danger it would react unfavorably upon the Sch. of Ind. and Iran. Stud. [sic]". Letter from W. N. Brown to H. H. Bender (8 October 1934). Box-P3627, File 919-2, NMAH 
As it turned out, the Indian National Congress committee refused permission for the exhibition of the Devanagari machine at its meeting in Bombay on the grounds that the machine was a "foreign invention". However, as Brown put it, with "an admirable carelessness for logic" the committee permitted its printing manager to have the machine installed otherwise for the printing of Congress material officially required for the meeting, in both English and Hindi. 48

The text to be printed thus was the presidential address, bearing an imprint of Linotype - a veritable endorsement of the machine, underscoring the incongruities of policy and utility. Set to be printed and circulated at a large scale, it is difficult to underestimate the influence this opportunity may have wielded in the acceptance of Mergenthaler's Devanagari. In an anticlimactic turn of events, however, after all the arrangements had been made, the sole Devanagari keyboard operator in the employ of Linotype - sent from Calcutta to Bombay for this purpose - could not compose the text in time owing to his lack of experience and slow composing speed.49 The work was eventually carried out at a local press by hand-setting using "about 50 compositors". ${ }^{\circ}$

This incident may only be a minor footnote in the early history of mechanical composition in Devanagari but it points to some of the most remarkable issues in the social and political contexts within which this history must necessarily be viewed. As the aspirations of progressive, modern, nationhood gathered force, the dilemmas of cultural identity, and questions about the place of modern technology in it, located themselves at the centre of the debate throughout India's pre- and postindependence period. ${ }^{1}$ Early in the first half of the century, the association of technology and modern machinery with oppression and state power was widely translated into a nationalistic anti-technology stance, especially against the "foreign". But within this broad ideological position, there was ample room to accommodate the utilitarian benefits of - and an active engagement with technology on a day-to-day basis.52 As exemplified in the Congress committee's ambivalent attitude towards Devanagari Linotype, the question of technology - even when "foreign" - was an open-ended, negotiable concern within the rhetoric of nationalism.

In developing the Devanagari machine and the accompanying typeface independently, whether or not Mergenthaler expected to demonstrate its supremacy in the market, or to limit intervention from the colony, local printing and publishing establishments - followed by a segment of the literate elite - responded largely by challenging its authority, and by asserting their own agendas in the sociopolitical

48 W. N. Brown, “Report no.1” (September 1934).

49 W. N. Brown, "Report no.5” (3 November 1934). Box-P3627, File 919-2, NMAH. The Devanagari operator, identified only as Iqbal, very likely a Bengali speaker not fully conversant with Devanagari, had about two days for the work and managed half of it before the "Congress authorities" realized that it would not be finished in time.

50 Ibid. This also underscores the availability and efficacy of cheap labour in the market where the machine was to compete.

51 See for instance, Milton Israel, Communication and Power: Propaganda and the Press in the Indian National Struggle, 1920-1947 (Cambridge: Cambridge University Press, 1994); Robin Jeffrey, India's Newspaper Revolution: Capitalism, Politics and the Indian Language Press 1977-1999 (London: Hurst \& Company, 2000); Francesca Orsini, The Hindi Public Sphere 1920-1940: Language and Literature in the Age of Nationalism (New Delhi: Oxford University Press, 2002); Robert Fraser, Book History through Postcolonial Eyes: Rewriting the Script (New York: Routledge, 2008).

52 See for instance Arnold, Everyday Technology, 10: "By the 1930s political activists, policemen, school teachers, and health workers arrived in villages on bicycles and used magic-lantern slides or cinema shows to entertain, educate, or cajole their audiences. They typed reports on their visits or phoned their superiors. When Gandhi arrived to speak against modern machines he frequently did so by motorcar, his thin voice amplified by the microphone and loud-speakers." 
context of language and script. Mergenthaler's enterprise enunciated power through technological exclusivity and large-scale production capability - areas that colonial subjects and local institutions were neither equipped to contest nor willing to sanction outright. However, the counter-bid for control could, and would, be made through a discourse of affiliation and ownership: of language, of script, of culture assets that could be translated into knowledge unavailable to Mergenthaler, especially not in the form of "usable information".

The contradictions and dilemmas relating to matters of policy and the extent of political involvement existed on both sides of the development of the Linotype - in India as well as in America. Govil, with whom Mergenthaler started developing the machine towards the end of 1931, had first approached the Company in 1924 for the same purpose. C. H. Griffith recalled in an official memorandum:

At that time [i.e. 1924] the printing and publishing industry in India was not in a prosperous condition, and there was little or no incentive for us to go ahead with this proposition. With the advent of the National movement in India during the latter part of 1930, [sic] and a series of Round Table Conferences between the British Government and Indian Nationals, held in London and elsewhere, interest in the native vernaculars, and particularly Hindi, was stimulated to a very great extent, and resulted in a wide-spread movement to improve and extend Indian national journalism. 53

It is important to note the connection of the nationalist movement with the development of printing in vernacular languages, and its consequent influence in Mergenthaler's decision to undertake the Devanagari development in the 1930s, and not in 1924. Although in part the Devanagari Linotype came about as an acknowledgement of India's political awakening and a response to its burgeoning propaganda apparatus, Mergenthaler made it a point to guard its commercial interests by adopting a non-partisan approach, ideologically steering clear of the forces behind local demand in India. However, once the machine was put on the market it was apparent that, in the prevailing political climate, arguments for speed and utility alone were not sufficient to sell it. The contradictions in Mergenthaler's non-partisan approach were amplified when, operating between ideologically opposite camps, the Company resorted to obfuscating the machine's British and American connections.

The "wide-spread movement" in the 1930s that Griffith had observed in his memorandum was another program accommodating contradictions - it not only sought widening the reach of print communication with improvement in the printing and publishing of the regional vernaculars, but also envisioned countrywide political unification through evolving consensus on a national language and a common script for India. Devanagari was largely promoted as the "all-India" script, though not without necessary modifications required to represent the non-Hindi sounds of various languages of the country. In this scenario, the phenomenon of Devanagari "script reform" found a fertile public arena for the playing out of political, technological, and typographic aspirations.

Whether set by hand or mechanically composed, metal type had obvious physical restrictions in representing syllabic scripts like Devanagari that require a great degree of overlap and overhangs in their formation (see Figure 2) - a characteristic not conducive to the linear setup deriving from an alphabetic script system. For the most part, hand-set Devanagari type did not offer the advantages of speed, efficiency, or quality in the script's representation, prompting efforts to "modernize" the script itself - which generally meant adopting characteristics of a linear alphabet. However, the introduction of mechanical typesetting for Devanagari in the 1920 s 
and 30 - precisely with its promise of speed and efficiency - introduced further problems and restrictions in the representation of the script. The large number of characters required for text composition in Devanagari could not be accommodated on standard keyboards and technological adaptations tended towards a

"simplification" of the script by reducing the number of characters to a bare minimum and approximating the principles of syllabic composition. Starting in the last quarter of the nineteenth century the interplay of nationalist sentiment, notions of technological progress and modernity, along with long-standing problems of efficiency in typesetting had thus initiated a period of intense "script reform" activity in India, where several proposals were made by politically and culturally engaged individuals, as well as institutions, to simplify or modify Devanagari characters. No consensus could be achieved on these proposals that varied from slight modifications of the script to total graphic and systemic overhauls. The "reform" of Devanagari eventually managed to attain a very small measure of departure from the script's original form and structure, though it did pave the way for a serious appraisal of issues related to its formal aspects and its standardisation.

A number of script reform schemes for Devanagari had indeed been proposed and put to test prior to the introduction of mechanical typesetting in the early $1930 \mathrm{os} .54$ Among other issues, these had addressed ways to make text-setting faster and easier, but with assurances for the same offered by mechanical composition, a general shift in focus towards a more adaptive approach could be discerned across the schemes in the wake of Devanagari Linotype. On the one hand, this resulted in numerous reform schemes finding their primary function in furthering the agendas of national integration, usually by advocating a new common system of notation. But progressively it also meant that the reform proposals could be more and more radical, concerned largely with the abstract expression of tradition, modernity, or "scientific" reorganization through the modified script, rather than with the devising of practical solutions.

Mergenthaler's Devanagari had met with opposition immediately following the launch of the machine in 1933. Objections had focused partly on the design of the typeface, which was found to be too light and cramped, and partly on the manner of composition, which gave a distinctly unconventional appearance to the text. To accommodate the large number of Devanagari characters (600-80o in foundry type) on a standard Linotype keyboard (with 90 keys), Govil's system of composition employed components of letters, divided vertically, which could then be combined to form complete individual letters. This would have been workable and unremarkable were it not for the Linotype machine's inability to accommodate overhangs in composition - a key requirement for Devanagari. Effectively, Linotype composition, much like some other reform proposals, presented a reduced modification of the script. In this context of the machine's reception, Mergenthaler could not afford to ignore the reform initiatives and activities around the standardization of Devanagari. Though its financial commitment had already been made in developing the machine according to Govil's system, the Company had to acknowledge the evident risks in pursuing its own line of argument too strongly. New developments in the political arena, and the vagaries of national opinion in a crucial period of transition, could veritably result in the whole development being scrapped. ${ }^{55}$ In addition, the authorization of the reform movement by the appointment of committees at national level, with numerous conferences across the country, lent the entire enterprise of script reform a sense of urgency and importance - and not the least, transformative

\footnotetext{
54 Naik, Typography of Devanagari, vol. 2, 471. Naik lists more than fifteen reform schemes and proposals in the period leading up to mechanical composition in the $1930 \mathrm{~s}$.

55 The example of the Turkish adoption of the Latin alphabet was evoked frequently in the exchange between people involved in Mergenthaler's Devanagari project, and the possibility of radical change in policies could not be overruled in the contemporary political climate.
} 
power that could dictate what Mergenthaler's "vernacular" machines were expected to produce.

Mergenthaler found itself in a decidedly precarious position in this milieu - being an interested commercial body, the Company could not have a valid say in the matter of script reform. Nor did it want to get involved in the political fray on the grounds that the authority for modification and standardization lay with the appropriate national committees. However, by the very existence and influence of the system that the Devanagari Linotype machine provided, it was often assumed that Mergenthaler would act as both adjudicator and facilitator of new schemes. The authors of many reform proposals also assumed that the Company would oblige and produce test versions of their suggested modifications. Linotype's India offices, managed by British staff not conversant in local languages or scripts, could not provide much help besides forwarding the many proposals and reform schemes they received, from the 1930 s well into the 1960 s.56 Remarkably, after Indian independence, the "script reform" activity of the earlier decades gradually turned into a "script standardisation" project. This change of rhetoric signalled the consolidation of the numerous disconnected and independent initiatives of the previous era under newly appointed governmental bodies that held a different kind of authority in independent India compared to what the traditional, reformist, or nationalist arguments for script change had possessed under the colonial administration. For Mergenthaler, this was the beginning of a long engagement with Devanagari and other Indian scripts. The users of the machine, on the other hand, found themselves in a position of active participation, in what was to become a revision continuum. Lasting as long as Linotypes were employed for Devanagari typesetting, this was to be a process fraught with dissatisfaction and incessant modification - and in the technological deadlock of hot-metal, a process driven largely by the constancy of contradictory preferences. (Figure 3)

\section{Conclusion}

The network of individuals and institutions involved in typographic design in India had a crucial role in shaping, and prioritising, the possibilities of printing in the country's many languages. A combination of local and international actors, this network enabled not only the realization of print through technical expertise but also cultural validation and the pursuit of political aspirations through language and script. The production of printed matter could not be achieved without the mediation of a range of interested bodies that exercised their own rationale and agency in determining what was thus enabled. In pre-independence India, given the nuances of power struggles inherent in decisions related to language and script, the process of typographical change also afforded a space where colonial ideology could be "both transmitted and queried, produced and challenged".57

Mergenthaler's Devanagari project had taken place within a framework that had prioritized completing the development first and seeking approval from its potential users as a subsequent step. The reception of the project and the gradual buildup of the "script reform" movement, on the other hand, had embraced an egalitarian process that called for active mass involvement in the written and printed manifestations of the script to shift the power balance. Whereas Mergenthaler

\footnotetext{
56 See for instance proposals by Y. M. Nanal, H. H. Bender to C. H. Griffith (21 November 1934) BoxP3627, File 919-2. Proposal by K. N. Misra (Misra scheme), W. N. Brown to C. H. Griffith (2 December 1945) Box-P3618, File 919-A. Proposal by Shrinivas of Benaras, W. N. Brown Report (29 March 1947). Proposal by Motilal Gurtu, W. N. Brown to C. H. Griffith (24 December 1948). Proposal by Satyendra Kumar Gupta, W. N. Brown to C. H. Griffith (1 January 1949). Letter from Balchandra Shankar Sathe (19 March 1950) Box-P3627, File 919-3, NMAH

57 As noted in a different context by Francis O'Gormon, The Victorian Novel (London: Michael Joseph, 1994), 308.
} 
pioneered technical innovation and commercial entrepreneurship, the script reform movement generated a public platform for cultural aspirations, typographic and otherwise, in a politically charged environment. The improvements and changes proposed by various actors in this process were open-ended and incremental in most cases, and often with relatively little material investment in the particulars of the modification itself. Mergenthaler had, conversely, invested substantial amount of time and money in its Devanagari development with a view to its commercial feasibility in a potentially profitable market. The processes of script reform in India and Mergenthaler's project had so little in common that their eventual - and prolonged - encounter could not be expected to lead to definite resolutions. It did, however, contribute immensely to a brief florescence of typographic engagement across the country.

\section{Abbreviations}

NMAH: Mergenthaler Linotype Company Records, National Museum of American History, Smithsonian Institution, Washington DC

\section{Acknowledgements}

The author would like to acknowledge the following individuals and the associated institutions for their help with archives-related access:

Cathy Keen, Joe Hursey, Alison Oswald, Craig Orr, Kay Peterson, and Wendy Shay at the Archives Centre, National Museum of American History, Smithsonian Institution, Washington DC [Mergenthaler Company Records]

Frank Romano at the Museum of Printing, North Andover, MA [Mergenthaler Font Library]

Joseph-James Ahern and Nancy R. Miller at the University of Pennsylvania Archives, Philadelphia PA [W. Norman Brown Papers]

Rossy Mendez at the Seeley G. Mudd Manuscript Library, Princeton University Archives, Princeton NJ [Office of Communications Records]

Jan Shearsmith at the Museum of Science and Industry, Manchester [Linotype \& Machinery Co. Ltd. Collection]

Fiona Ross at the Department of Typography \& Graphic Communication, University of Reading [NonLatin Type Collection]

\section{Sources cited}

“India’s Culture”, The Brooklyn Daily Eagle (13 April 1930)

"Project to Further Human Knowledge: Garrett Collection of Manuscripts to be Edited - University Press to Publish Results with New Equipment”, The Princeton Alumni Weekly (5 April 1929)

"Teaching a sixth of the world to read: now a machine is to carry literacy to India" New York Herald Tribune (18 June 1933)

“Typographical Font”, Hari G. Govil, US Patent (filed 1933, granted 1937)

Arnold, David. Everyday Technology: Machines and the Making of India's Modernity. Chicago and London: University of Chicago Press, 2013.

Boag, Andrew and Christopher Burke (eds.) History of the Monotype Corporation. London: PHS and Vanbrugh Press, 2014.

Das, Sisir Kumar. Sahibs and Munshis: an Account of the College of Fort William. New Delhi: Orion Publications, 1978.

Dalmia, Vasudha. The Nationalization of Hindu Traditions: Bharatendu Harischandra and NineteenthCentury Banaras. Delhi: Oxford University Press, 1997. 
Edgerton, David. The Shock of the Old:Technology and Global History since 19oo. London: Profile Books, 2006.

Eisenstein, Elizabeth L. The Printing Press as an Agent of Change: Communications and Cultural Transformations in Early-Modern Europe. Cambridge: Cambridge University Press, 1979.

Fedirka, Sarah A. Towards a Locational Modernism: Little Magazines and the Modernist Geographical Imagination. Arizona State University, 2008.

Fraser, Robert. Book History through Postcolonial Eyes: Rewriting the Script. New York: Routledge, 2008.

Freitag, Sandria B. Collective Action and Community: Public Arenas and the Emergence of Communalism in North India. Delhi: Oxford University Press, 1990.

Hobsbawm, Eric. Age of Extremes : the Short Twentieth Century 1914-1991. London: Michael Joseph, 1994.

Israel, Milton. Communication and Power: Propaganda and the Press in the Indian National Struggle, 1920-1947. Cambridge: University Press, 1994.

Jeffrey, Robin. India's Newspaper Revolution: Capitalism, Politics and the Indian Language Press 19771999. London: Hurst \& Company, 2000.

Kesavan, B.S. History of Printing and Publishing in India: a Story of Cultural Reawakening. 3 volumes. New Delhi: National Book Trust, 1997.

King, Christopher R. One Language, Two Scripts: the Hindi Movement in Nineteenth Century North India. Bombay: Oxford University Press, 1994.

Masten, Jeffrey, Peter Stallybrass, and Nancy Vickers (eds.). Language Machines: Technologies of Literary and Cultural Production. New York, London: Routledge, 1997.

Monier Williams (ed.), Original Papers Illustrating the History of the Application of the Roman Alphabet to the Languages of India. London: Longmans, Brown, Green, Longmans, and Roberts, 1859.

Mukul, Akshaya. Gita Press and the Making of Hindu India. Noida: HarperCollins, 2015.

Naik, Bapurao S. Typography of Devanagari. 3 volumes. Bombay: Directorate of Languages, 1971.

O’Gormon, Francis. The Victorian Novel. London: Michael Joseph, 1994.

Orsini, Francesca. The Hindi public sphere 1920-1940: language and literature in the age of nationalism. New Delhi: Oxford University Press, 2002.

---. (ed.) The History of the Book in South Asia. Surrey: Ashgate, 2013.

Priolkar, Anant K. The Printing Press in India: its Beginnings and Early Development. Bombay: Marathi Samshodhana Mandala, 1958

Rai, Alok. Hindi Nationalism. New Delhi: Orient Longman, 2001.

Romano, Frank. History of the Linotype Company. Rochester: RIT Press, 2014.

Ross, Fiona G. E. The Printed Bengali Character and its Evolution. Surrey: Curzon Press, 1999.

Shaw, Graham. "Printing in Devanagari: the Evolution of Types in Devanagari Script", Monotype Recorder, new series no.2 (1980): 28-32.

Singh, Vaibhav. "Devanagari type in the twentieth century: motivations, imperatives, technology, and the design process". Unpublished PhD thesis, 2017.

Southall, Richard. Printer's Type in the Twentieth Century: Manufacturing and Design Methods. New Castle and London: The British Library and Oak Knoll Press, 2005.

Stark, Ulrike. An Empire of Books: the Naval Kishore Press and the Diffusion of the Printed Word in Colonial India. New Delhi: Permanent Black, 2007.

Trevelyan, Charles, The Application of the Roman Alphabet to All the Oriental Languages. Serampore: Serampore Press, 1834 . 